\title{
MODEL OF SISTER CITY COOPERATION IN ORDER TO IMPROVE REGIONAL DEVELOPMENT IN BANYUMAS REGENCY ${ }^{\Omega}$
}

\author{
Noer Indriati, Sanyoto, Aryuni Yuliantiningsih, Agus Mardianto and Wismaningsih \\ Faculty of Law Universitas Jenderal Soedirman \\ E-mail: sunoboputri40@gmail.com
}

\begin{abstract}
The world has entered an era of openness, the nation that choose to close from international relations will be excluded from modern civilization. Sister city is the concept of coupling of two different cities and political administration with the aim of establishing relationships of cultural and social contact between people. This paper used statutory approach, with a qualitative analysis of the juri-dical. Cooperation with overseas regions are snowball, which mean begins with one thematic coope-ration and can be resume in other fields. Sister city cooperation can increase foreign exchange thereby increasing regional development. Cooperation in the Regency of Banyumas has yet to be re-alized, and reach new level of offerings to the country's area contact.
\end{abstract}

Keywords: authority, international treaties, sister city

\begin{abstract}
Abstrak
Dunia telah memasuki era keterbukaan sehingga bangsa yang memilih untuk menutup diri dari pergaulan internasional akan menjadi bangsa yang tersisih dari peradaban modern. Kota kembar adalah konsep penggandengan dua kota yang berbeda lokasi dan administrasi politik dengan tujuan menjalin hubungan budaya dan kontak sosial antarpenduduk. Tulisan ini menggunakan pendekatan perundangundangan, dengan analisa yuridis kualitatif. Kerjasama dengan daerah di luar negeri bersifat snowball, artinya diawali dengan satu kerjasama tematik, dapat dilanjutkan kerjasama di bidang lainnya. Kerjasama sister city dapat menambah devisa negara sehingga dapat meningkatkan pembangunan daerah. Kerjasama ini di Kabupaten Banyumas belum dapat terwujud, dan baru mencapai tingkat menawarkan, sehingga belum terdapat daerah dari negara lain yang menghubungi.
\end{abstract}

Kata kunci: kewenangan, perjanjian internasional, kota kembar

\section{Introduction}

Based on the geographical and land transportation network maps, Purwokerto is very strategic as it becomes a node centers of economic growth, Cilacap, Yogyakarta, Bandung, Cirebon, whether on good road networks or railways. Purwokerto is $50 \mathrm{Km}$ away from Cilacap where there is Port of Samudera Tanjung Intan and Tunggul Wulung Airport. Topographically Banyumas is consist of more than $45 \%$ lying areas which are scattered in central and southern parts, and from west to east. Altitude most of the region is in the range of $25-100 \mathrm{M}$ above sea level covers an area of 42310.3 hectares and 100-500 $\mathrm{M}$ above sea level covers an area of

\footnotetext{
$\Omega$ This paper is part of the research with LPPM Unsoed Chairman Decree No Kept.4893/UN23.14/PN.01.00/2015
}

40385.3 hectares, while others are between 500 up to more than $1,000 \mathrm{M}$ above sea level.

The total area of Banyumas Regency approximately is $1327.60 \mathrm{~km} 2$, equivalent to $132,759.56$ ha, with the condition of the area between the land and the mountains with mountain structure consists of most of the Serayu river valley for agricultural land, most of the plateau for the settlement and its grounds, and partly of the mountainous for plantations and tropical forest located on the slopes of Mount Slamet in the south of Earth and the wealth of Banyumas Regency has still quite a potential for Slamet mountain with a summit elevation of sea level is about $3.400 \mathrm{M}$ and it is still active. Banyumas regency consists of 27 districts which are divided over a number of 30 kelurahan and 
301 desa. Banyumas Regency Government has not had sister city cooperation yet and hopefully with its potential can be established sister city with foreign partners.

Nowadays, countries tend to regulate and make the international relations in the form of written international agreement. It is based on interdependence and mutual need of one country toward another, whether it is natural resources, energy, information, technology, or even trade.

The historical aspect of the ongoing abroad cooperation relations by the Local Government started from the birth of Municipal International Cooperation (MIC). ${ }^{1}$ According to the Local Government Association of the Netherlands that the MIC is a cooperative relationship between two or more communities, where at least one of the main protagonists are the municipality, district, provincial and/or state.

This paper uses the term of model because international treaties generally are held by the state with the state or other subjects of international law. Article 2 of the 1969 Vienna Convention states that "the agreement is approved by one country with another country, subject to international law with one or more instruments and give rise to legal consequences". Sister city is one model of international cooperation undertaken by the region in a country with region in other countries. Sister City is the concept of the union of two different city locations and political administration with the aim of establishing cultural relations and so-cial contract between residents. Sister City generally have similar demographics and problems faced. Sister city concept can be thought of as friends between the two cities. The relation of the Sister city is very helpful for the cooperation program in the field of culture and trade.

\section{Problem}

This paper will discuss how to create a sister city cooperation which can be used in an

\footnotetext{
1 Jemmy Rumengan, "Perspektif Hukum dan Ekonomi atas Kerjasama Luar Negeri oleh Pemerintah Daerah", Jurnal Hukum Internasional, Vol 6, No. 2, 2009, Jakarta: Universitas Indonesia, page 241.
}

effort to improve development in Banyumas Regency?

\section{Reseach Methods}

This doctrinal research used statute approach because the object which examined are various rules of law that become the focus and the central theme of the research. The approach method that used is legislation approach that serves and lead to the issued of the policy and appears as the concept of public policy. Primary Data is used to support secondary Data Obtained through interviews. The analytical method used is analysis methods of the juridical qualitative data.

\section{Discussion}

Create Sister City Cooperation That Can be Used as an Effort to Improve Development In Banyumas Regency

An International agreement's nomenclature may be varied, but if it is studied further, grouping certain agreements in the title is intended to indicate a substance regulated similarity. The use of certain titles on an international agreement is also carried out to demonstrate that the agreement material weighs different levels of cooperation with other international agreement, and even to show a link between such international agreements with other international agreements that have been made previously.

1969 Vienna Convention on the Legal agreement, does not do distinctions made in various forms of international agreements. In addition, Article 102 of the Charter of the United Nations only distinguishes international agreement under the terms of treaty and international agreement, which up to now there is no clear definition between the two terms. ${ }^{2}$ Practice making the agreement between the coun-

\footnotetext{
2 Sugiarto Pramono, “Hubungan Luar Negeri Indonesia Era Otonomi Daerah. Sister province (Provinsi Kembar) Jawa Tengah Dengan Negara Bagian Queensland Australia Periode Tahun 2000-2007-Faktor Pendorong Melakukan Kerjasama Sister Province Jateng-Australia 1991-2009 oleh (staf pengajar Fakultas Ilmu Sosial dan Ilmu Politik), Jurnal Hubungan Internasional, Semarang: Universitas Wahid Hasyim.
} 
tries had been spawned various forms of terminology of international treaties, which sometimes differ usage by country, region and type of devices internationally. The terminology used by the international instruments generally do not reduce the rights and obligations contained.

In Law Number 22 Year 1999, the area can do foreign relations. Therefore, the sister city cooperation relationships has a strategic meaning because the convergence of city's center growth and development in a mutually beneficial cooperation. Sister city cooperation in conformity with international law (1969 Vienna Convention, 1963 Vienna Convention and 1969 Vienna Convention), National Law (Law Number 22 Year 1999, Law Number 37 Year 1999, Law Number 24 Year 2000, Law Number 20 Year 2003 and Decree of the Minister of Foreign Affairs of the Republic of Indonesia Number 03/ AIOTIX/ 2003). ${ }^{3}$

Sister City is done to make easier network of economic cooperation, culture, education, and various fields in accordance with the core competencies of a city/regency that can be mutually beneficial. Article 4 of the Regulation of Ministry of Home Affairs No. 03 Year 2008 confirms that before establishing a Sister City partnership, the local government must fulfill variety of requirements: first, Diplomatic Relations. Areas that will be cooperated must have diplomatic relations with Indonesia. Second, do not open representative offices abroad. The meeting between representatives of the area is not diplomatic but only in the form of delegation. Third, It is the Local Government Affairs. All the problems and the agreement made during the Sister City program is the responsibility of each local authority involved. Fourth, not lead to interference in its internal affairs. Fifth, In accordance with the policies and development plans. Sister City Cooperation should not be carried incidentally.

The fall of the New Order(Orde Baru) on May 16, 1998, and the subsequent birth of the

\footnotetext{
3 Eka Titiyani A., "Efektivitas Kerjasama Sister City Kota Semarang (Indonesia) Dengan Brisbane (Australia) Tahun 2002-2007", Jom FISIP, Vol. 1 No. 2, October 2014, Semarang: Universitas Diponegoro, page 2.
}

Reform Order that one of the agenda to amend the 1945 Constitution, among other things because the 1945 Constitution gives enormous power to the executive. It has made a system of authoritarian rule to be changed with more systems to guarantee a balance between the executive and legislative institution. ${ }^{4}$ Before the first amendment, the power to establish law by the President and since the amendment, the po-wer held by Parliament. ${ }^{5}$

The Practice in Indonesia distinguishes international agreements which require the approval of Parliament and that does not require the approval of Parliament. It is very important, international agreements concerning the interests of citizens; which resulted in changes to national legislation; and the resulting changes in the region takes its implementing regulations. ${ }^{6}$ The international agreement can be compared with the agreement between the regions in Indonesia with an area of friendly countries known as "the sister agreement". Sister agreement is not a treaty, because it does not qualify under the Vienna Convention on the Law of Treaties 1969 concerning Law of Treaties. ${ }^{7}$

Forms of Cooperation with Foreign Local Government, are: first, the cooperation of provincial and district/city "twins" Government to Government; second, technical cooperation including humanitarian assistance Government to non-Government; and third, Local Govern-ment and Private Cooperation Government to Private;

\footnotetext{
4 I Wayan Parthiana, "Kajian Akademis (Teoritis dan Praktis) atas Undang-Undang Nomor 24 Tahun 2000 Tentang Perjanjian Internasional Berdasarkan Hukum Perjanjian Internasional", Jurnal Hukum Internasional (Indonesian Journal of International Law)-UI, Vol. 5 No. 3, April 2008, Jakarta: Law Faculty Universitas Indonesia, page 471.

5 AA. Oka Mahendra, "Harmonisasi dan Sinkronisasi Rancangan Undang-undang Dalam Rangka Pemantapan dan pembulatan Konsepsi”, Jurnal Legislasi Indonesia, Vol. 2 No. 3, September 2005, Jakarta: Direktorat Jenderal Peraturan Perundang-undangan Departemen Hukum dan HAM, page 123-124.

6 Melda Kamil Ariadno, "Kedudukan Hukum Internasional Dalam Sistem Hukum Nasional”, Jurnal Hukum Internasional (Indonesian Journal of International Law), Vol. 5 No. 3 April 2008, Jakarta: Lembaga Kajian Hukum Internasional-FH.UI, page 522

7 Hikmahanto Yuwana, "Catatan Atas Masalah Aktual Perjanjian Internasional", Jurnal Hukum Internasional-Indonesian Journal of International Law, Vol. 5 No. 3, April 2008, Jakarta: Lembaga Pengkajian Hukum Inter-nasional Faculty of Law Universitas Indonesia, page 450.
} 
The authority is the power which formalized, either toward a particular person or group of people or toward the power in government unanimously derived from legislative power and from the power of government. ${ }^{8}$ Beside the term authority, there is also term competence (competence, bevoegheid). The competence is the ability to perform acts of public law, or juridically, competence is the ability to act in a given law applies to legal relations. ${ }^{9}$

Opportunities for the convening of foreign relations and cooperation between the district and city autonomous regions is possible and opens opportunities widely, both in the form of sister province cooperation or a sister city. Law Number 37 Year 1999 concerning Foreign Relations, Chapter I General Provisions, Article 1 point 6 states that:

Autonomous regions which is called as the area, is a unity of community bound-aries have authorized organize and administer governmental affairs and public interests own initiative based on the aspirations of the people within the Unitary Re-public of Indonesia system.

Based on the principle of broad autonomy, real and responsible, so the autonomous regions may be given broad authority to govern and manage the affairs of his own household. In addition the Local Government Autonomous District and City are also given the authority to be able to conduct foreign relations and cooperation in the framework of efforts to develop the region. ${ }^{10}$ Law Number 32 Year 2004 that the principle of broad autonomy gives authority to the Autonomous Region to be able to govern by Part III of the Government Affairs Division, Article 10 until 18.

The direction of region development policy in Banyumas formulated with respect to the Long Term Development Plan of Regions, as follows: increasing economic growth and distribu-

\footnotetext{
8 Jawahir Thontowi, "Kewenangan Daerah Dalam Melakukan Hubungan Luar Negeri", Jurnal Hukum, Vol. 16 No. 2, April, 2009, Bandung: Universitas Padjadjaran, page 151.

9 Ibid. hlm.152

10 Noer Indriati, “Perjanjian Internasional Oleh Daerah Sebagai Kewenangan Otonomi Daerah", Jurnal Dinamika Hukum, Vol. 10 No. 1, Januari 2010, Purwokerto: Law Faculty Universitras Jenderal Soedirman, page 40.
}

tion with emphasis on the development of investment-based sectors in the regions and populist economic empowerment, which includes: first, construction investment is directed to improvement investment climate and realiza-tion of investment and increased promotion and investment cooperation; second, development of communications is directed to the construc-tion of infrastructure and transportation facili-ties and the rehabilitation and maintenance of infrastructure and facilities of traffic and road transport; third, tourism development aimed at improving community empowerment in the context of the development of tourism, the development of regional tourism sector development management and publication development and promotion of tourism in an integrated and sustainable.

Banyumas Regency ever establish cooperation with South Korea in 2014 but it did not continue. Cooperation can through certain fields, such as health, education, etc. should not be directly to the sister city cooperation, because the sister city cooperation can be a long-term range. The cooperation is not always oriented to the results or the advantage of money, but it can be in other forms.

With the Banyumas's potential has, it can do cooperation with overseas regions which are snowball, it means starting with a material agreement it can be done cooperation or agreements in other fields. This is an opportunity to expand Banyumas regency for cooperation. Banyumas has excellent schools, it can be used as a step to conduct cooperation in education with the mutual sharing of knowledge and culture. It started with the construction of facilities to $\mathrm{Wi}$ rasaba Purbalingga Airport through Kalicupak lane, has also provided five-star hotels that is minimumly international standard as well as agricultural products. Cooperation between one region and other regions in other countries need is clarity about what will be offered, scedule, and rules as well as its funding.

A few of overview in some districts which produces adequate product, ie from 27 districts. Potentials of agricultural crops for exam- 
ple, which can be used as an opportunity to of fer, are:

Table 1. Smallholder Crop Production by the Plant Type in 2011

\begin{tabular}{|l|l|r|r|}
\hline Plant Type & $\begin{array}{l}\text { Product- } \\
\text { ion Form }\end{array}$ & \multicolumn{1}{|c|}{$\begin{array}{c}\text { Total } \\
\text { produc- } \\
\text { tion (ton) }\end{array}$} & $\begin{array}{c}\text { Average } \\
\text { production } \\
\text { (kg/ha) }\end{array}$ \\
\hline Kelapa Dalam & Kopra & 12.892 .41 & 1.416 .62 \\
\hline Kelapa Deres & $\begin{array}{l}\text { Gula } \\
\text { kelapa }\end{array}$ & 52.114 .56 & 10.281 .58 \\
\hline $\begin{array}{l}\text { Kelapa } \\
\text { Hibrida }\end{array}$ & Kopra & 64.04 & 1.395 .51 \\
\hline Kopi Robusta & Wose & 85.93 & 315.20 \\
\hline Kopi Arabica & Wose & 9.58 & 567.37 \\
\hline Cengkeh & $\begin{array}{l}\text { Bunga } \\
\text { kering }\end{array}$ & 202.95 & 196.48 \\
\hline Karet & Getah & 39.51 & 869.36 \\
\hline Kapok & Odolan & 3.47 & 311.49 \\
\hline Teh & $\begin{array}{l}\text { Daun } \\
\text { kering }\end{array}$ & 67.03 & 1.483 .38 \\
\hline Panili & $\begin{array}{l}\text { Polong } \\
\text { kering }\end{array}$ & 0.91 & 191.58 \\
\hline Casiavera & Klika & 15.21 & 254.56 \\
\hline Jahe & Biji kering & 60.14 & 1.219 .38 \\
\hline Laos & Biji & 35.78 & 1.419 .84 \\
\hline Kencur & $\begin{array}{l}\text { Daun } \\
\text { kering }\end{array}$ & 29.28 & 2.361 .29 \\
\hline Kunyit & Biji kering & 95.80 & 2.350 .92 \\
\hline Temulawak & Biji kering & 38.30 & 2.333 .94 \\
\hline Tebu & Biji kering & 394.86 & 5.075 .85 \\
\hline Tembakau & $\begin{array}{l}\text { Jebug } \\
\text { kering }\end{array}$ & 14.84 & 611.96 \\
\hline Nilam & Rimpang & 472.39 & 2.466 \\
\hline & & & \\
\hline
\end{tabular}

Table 2. The harvested area, production and average production of bananas in the District in 2012

\begin{tabular}{|l|r|r|r|}
\hline \multicolumn{1}{|c|}{ Districts } & $\begin{array}{c}\text { Area har- } \\
\text { vested } \\
\text { (tree) }\end{array}$ & $\begin{array}{c}\text { Produc- } \\
\text { tion } \\
\text { (Quintal) }\end{array}$ & $\begin{array}{c}\text { Average } \\
\text { production } \\
\text { Kwt/tree }\end{array}$ \\
\hline Lumbir & 3.180 & 378 & 0,12 \\
\hline Wangon & 18.100 & 9.083 & 0,50 \\
\hline Jatilawang & 13.292 & 2.612 & 0,20 \\
\hline Rawalo & 69.475 & 6.557 & 0,09 \\
\hline Kebasen & 10.948 & 4.745 & 0,43 \\
\hline Kemranjen & 2.024 & 479 & 0,24 \\
\hline Sumpiuh & 2.895 & 4.575 & 1,58 \\
\hline Tambak & 20.000 & 14.150 & 0,71 \\
\hline Somagede & 9.151 & 2.842 & 0,34 \\
\hline Banyumas & 5.394 & 1.717 & 0,32 \\
\hline Patikraja & 4.055 & 1.286 & 0,32 \\
\hline Purwojati & 93.135 & 7.359 & 0,08 \\
\hline Ajibarang & 21.408 & 7.584 & 0,35 \\
\hline Gumelar & 69.203 & 34.601 & 0,50 \\
\hline Pekuncen & 4.459 & 2.498 & 0,56 \\
\hline Cilongok & 6.348 & 2.456 & 0,39 \\
\hline Karangluwas & 30.178 & 3.558 & 0,12 \\
\hline Kedungban- & 7.726 & 185 & 0,02 \\
teng & 10.110 & 2.700 & 0,27 \\
\hline Baturaden & & &
\end{tabular}

\begin{tabular}{|l|r|r|r|}
\hline Sumbang & 5.765 & 1.171 & 0,20 \\
\hline Kembaran & 13.400 & 35.675 & 2,66 \\
\hline Sokaraja & 3.100 & 1.443 & 0,47 \\
\hline
\end{tabular}

Table 3. The harvested area, production and average production of durian in the District in 2012

\begin{tabular}{|l|r|r|r|}
\hline \multicolumn{1}{|c|}{ Districts } & $\begin{array}{c}\text { Area har- } \\
\text { vested } \\
\text { (tree) }\end{array}$ & $\begin{array}{c}\text { Produc- } \\
\text { tion } \\
\text { (Quintal) }\end{array}$ & $\begin{array}{c}\text { Average } \\
\text { produc- } \\
\text { tion } \\
\text { Kwt/tree }\end{array}$ \\
\hline Kemranjen & 8.744 & 1.202 & 0,14 \\
\hline Sumpiuh & 5.801 & 297 & 0,05 \\
\hline Tambak & 1.500 & 2.403 & 1,60 \\
\hline Banyumas & 1.452 & 62 & 0,04 \\
\hline Patikraja & 6.615 & 629 & 0,10 \\
\hline Gumelar & 6.947 & 2.958 & 0,43 \\
\hline $\begin{array}{l}\text { Kedungban- } \\
\text { teng }\end{array}$ & 1.584 & 1.187 & 0,75 \\
\hline Kembaran & 1.921 & 3.013 & 1,57 \\
\hline
\end{tabular}

Table 4. The harvested area, production and average production of mango in the District in 2012

\begin{tabular}{|l|r|r|r|}
\hline Districts & $\begin{array}{c}\text { Area } \\
\text { harvested } \\
\text { (tree) }\end{array}$ & $\begin{array}{c}\text { Produc } \\
\text { tion } \\
\text { (Quin- } \\
\text { tal) }\end{array}$ & $\begin{array}{c}\text { Average } \\
\text { production } \\
\text { Kwt/tree }\end{array}$ \\
\hline Lumbir & 1.462 & 1.217 & 0,83 \\
\hline Wangon & 3.610 & 400 & 0,11 \\
\hline Jatilawang & 7.208 & 940 & 0,13 \\
\hline Kebasen & 12.532 & 563 & 0,04 \\
\hline Sumpiuh & 3.805 & 1.294 & 0,34 \\
\hline Tambak & 3.000 & 150 & 0,55 \\
\hline Somagede & 2.307 & 32 & 0,01 \\
\hline Banyumas & 2.743 & 274 & 0,10 \\
\hline Patikraja & 1.375 & 811 & 0,59 \\
\hline Purwojati & 15.137 & 1.513 & 0.10 \\
\hline Ajibarang & 1.981 & 692 & 0,35 \\
\hline Gumelar & 11.656 & 17.184 & 1,47 \\
\hline Kalibagor & 33.11 & 1.557 & 0,47 \\
\hline Kembaran & 1.103 & 2.116 & 1,92 \\
\hline Sokaraja & 2.378 & 358 & 0,15 \\
\hline \multicolumn{2}{|l|}{ Source: Banyumas Regency in 2013 }
\end{tabular}

Banana production, looks very much which is produced in 22 sub-district that is offered to the overseas, with an estimated during the time the agreement is fulfilled all the requirements. Coconut sugar is also a product that makes it possible to offer for cooperation. This research is the first step to create a sister city cooperation. Sister city cooperation can not be directly created but must go through the long steps. The initial steps are as follows: 
Scheme 1. Shipping List Process

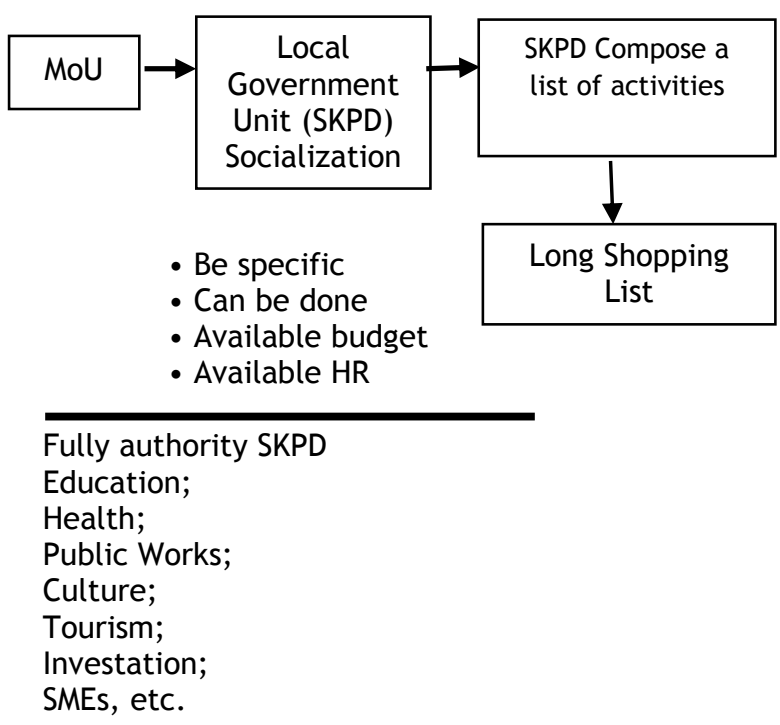

In the action plan process, the region was asked to draw up a shopping list that is a record of what will be offered to the cooperation. Shopping list must be communicated to the parties to the cooperation can be agreed, after a deal it will be implemented. Shopping list process is done by the Local Government Unit (SK PD), because SKPD who knows the potential that exists in the area. Long Shopping List should be specific, workable, available budget and human resources. At the beginning of the pilot has made shopping list and have been sent to the Interior Ministry. Shopping list consists of Sugar crys-tals, Batik, Tourism, Gurameh, Oil Asiri.

According to the theory of cooperation, basically every human being is a social being who tend to cooperate with others. More broadly, this theory also applies to each region, no single area that can meet its needs completely independently. Each area would require another area that can be a buffer to meet their needs. Contained three main elements attached to a framework for cooperation in that sense, there are: elements of two or more parties, the interaction elements and elements of a common goal. If one of these elements not contained in the object under study, it can be considered that the object was not found cooperation. Ele- ments of the two parties, which always describe a set of mutually influence each other so that interaction to achieve common goals is important. Relationship or interaction was not aimed at the fulfillment of the interests of each party, the relationship is not a partnership. An interaction is dynamic though, does not always mean cooperation. An interaction which is intended to meet the interests of other parties involved in the process of interaction, nor a partnership. Cooperation always putting the parties interact on an equal footing, and harmony.

The indicator is used to measure the implications are becoming more widespread also not just economic indicators only. The criteria used in the process of formulating the strategy/ policy development is also changing in the field of public policy, no longer just economic criteria, such as revenue growth, growth in consumption, investment, growth rates and the amount of import or export and so on. Goal to create regional economic growth, encourage Efforts to Realize the independence of the region, improving the ability of the region in global competition, to Realize the cooperation between Cities/areas of mutual benefit, and to create international networking and international friendship, but Also include the level of political dependence and the economy to the outside domestic, national security and global stability, the ability of self-reliance an autonomous region, and others.

Before drawing up and approving the plan, the regency/city government should equip themselves with accurate calculations, do study data and the power of a good profile between the two parties. The goal is to bear all the potentials that can be developed ("sell"), these potentials may be material in the technical plan.

Cooperation with regions in abroad is snowball, which means it is started with an agreement that can be carried out cooperation in other fields. Banyumas regency's existing potential can do cooperation. This is an opportunity to expand Banyumas regency for cooperation. Banyumas has excellent schools, it can be used as a step to conduct cooperation in educa- 
tion with the mutual sharing of knowledge and culture. Start a means of getting the airport built Wirasaba Purbalingga ie Kalicupak lines, has also provided five-star hotels that is minimumly international standard as well as agricultural products. Cooperation between one region and in other countries need is clarity about what will be offered, scedule and rules as well as its funding.

Special shopping list must be constantly monitored and success in implementing the Sister City partnership would require several factors: ${ }^{11}$ first, the strong support and involvement of local governments either directly or indirectly; second, support from communities and individuals who are very enthusiastic with this program; third, Forming an alliance in order to maximize limited resources and potential and impact of the Sister City program in the community; fourth, good communication link is very important to connect the network communicates of the prime quality, including reliable phone, fax and internet communication to maintain good relations; fifth, sensitivity to cultural differences, so this program should be balanced, planned, implemented and evaluated jointly; sixth, Have a clear goal, to preserve and maintain the program remains active then it is very important for every city to meet up annually to develop the MOU on what they corporate; seventh, low cost exchange activities every year, even if it is not possible to have the exchange of people physically; eighth, exchange-regular exchanges is very important to agree on an exchange of one person who is constantly each year, including the exchange of teachers and students; ninth, Dare to take risks, all relationships have to be willing to take risks for more ambitious projects to keep them fresh, and reach its full potential. This project certainly requires a high level of planning, fun-draising, time and effort, so that all fields are involved.

\footnotetext{
${ }^{11}$ Rohman, G. dan Hudalah, D, "Evaluasi Kebijakan Kerjasama Antarkota 'Sister City' Kota Surabaya”, Jurnal Pe rencanaan Wilayah dan Kota A, Vol. 2 No. 2, 2013, page 2-4, Available on web: http://penataanruang.pu.go.id/ bulletin/upload/data_artikel/edisi3i.pdf, accessed on 26 October 2015
}

\section{Conclusion}

Sister City cooperation has not been created yet in Banyumas Regency. Banyumas Regency has been running until bidding (shopping (ist) and wait there are others who contacted so that it can proceed to the establishment of cooperation.

\section{Recomendation}

Banyumas regency government should kindly continue to monitor the deals included in the shopping list.

\section{Refferences}

A, Eka Titiyani. "Efektivitas Kerjasama Sister City Kota Semarang (Indonesia) dengan Brisbane (Australia) Tahun 2002-2007". Jom FISIP. Vol. 1 No. 2. October 2014. Semarang: Social and Political Science Faculty Universitas Diponegoro;

Ariadno, Melda Kamil. "Kedudukan Hukum Internasional Dalam Sistem Hukum Nasional". Jurnal Hukum Internasional (Indonesian Journal of International Law). Vol. 5 No. 3. April 2008. Jakarta: Lembaga Kajian Hukum Internasional-FH.UI;

G, Rohman dan Hudalah. D.. "Evaluasi Kebijakan Kerjasama Antarkota 'Sister City' Kota Surabaya". Jurnal Perencanaan Wilayah dan Kota A. Vol. 2 No. 2. 2013. Available on web: http://penataanruang.pu. go.id/bulletin/upload/data_artikel/edisi3 i.pdf. Accessed on 26 October 2015

Indriati, Noer. “Perjanjian Internasional Oleh Daerah Sebagai Kewenangan Otonomi Daerah". Jurnal Dinamika Hukum. Vol. 10 No. 1. January 2010. Purwokerto: Faculty of Law Universitas Jenderal Soedirman;

Mahendra, AA Oka. "Harmonisasi dan Sinkronisasi Rancangan Undang-undang Dalam Rangka Pemantapan dan pembulatan Konsepsi”. Jurnal Legislasi Indonesia. Vol. 2 No. 3. September Tahun 2005. Jakarta: Direktorat Jenderal Peraturan Perundangundangan Departemen Hukum dan HAM;

Parthiana, I Wayan. "Kajian Akademis (Teoritis dan Praktis) atas Undang-Undang Nomor 24 Tahun 2000 Tentang Perjanjian Internasional Berdasarkan Hukum Perjanjian Internasional". Jurnal Hukum Internasional (Indonesian Journal of International 
Law)-UI. Vol. 5 No. 3. April Tahun 2008. Jakarta: Universitas Indonesia;

Pramono, Sugiarto. “Hubungan Luar Negeri Indonesia Era Otonomi Daerah. Sister province (Provinsi Kembar) Jawa Tengah Dengan Negara Bagian Queensland Australia Periode Tahun 2000-2007-Faktor Pendorong Melakukan Kerjasama Sister Province Jateng-Australia 1991-2009 oleh (staf pengajar Fakultas Ilmu Sosial dan Ilmu Politik). Jurnal Hubungan Internasional. Semarang: Universitas Wahid Hasyim;

Rumengan, Jemmy. "Perspektif Hukum dan Ekonomi atas Kerjasama Luar Negeri oleh Pemerintah Daerah". Jurnal Hukum Internasional. Vol 6. No. 2. 2009. Jakarta: Universitas Indonesia;

Thontowi, Jawahir. Kewenangan Daerah Dalam Melakukan Hubungan Luar Negeri. Jurnal Hukum. Vol. 16 No. 2. April . 2009. Bandung: Universitas Padjadjaran;

Yuwana, Hikmahanto. Catatan Atas Masalah Aktual Perjanjian Internasional. Jurnal Hukum Internasional-Indonesian Journal of International Law. Vol. 5 No. 3. April 2008. Jakarta: Lembaga Pengkajian Hukum Internasional Faculty of Law Universitas Indonesia. 